\title{
Seasonal variation of phytoplankton diversity, density and palmer's pollution index of freshwater lake, rural area of Ahmedabad
}

N. R. MULIA, N.G. KOTADIYA AND C. A. ACHARYA

Author for Corresponding -

\section{N. R. MULIA}

Department of Botany, M.G. Science Institute, Navrangpura, AHMEDABAD (GUJARAT) INDIA Email: nileshmulia@gmail.com

See end of the article for

Coopted authors'
ABSTRACT...... The present study was carried out on Manipur lake of Manipur village. The plankton were collected, counted and were identified by using the method suggested by APHA (1985); Prescott (1970) and Edmondson (1959). The planktons were counted by using Sedgwick Rafter counting cell. Different class such as cyanophyceae, chlorophyceae, bacillariophyceae and euglenophyceae. Among all these classes the listed phytoplankton such as Anabaena sp., Merismopedia sp., Ankistrodesmus sp., Actinastrum sp., Closteriopsis sp., Closterium sp., Coelastrum sp., Crucigenia sp., Gonium sp., Pediastrum sp., Scenedesmus sp., Tetraedron sp., Amphiplrura sp., Cyclotella sp., Cymbella sp., Navicula sp., Nitzschia sp., Synedra sp., Euglena sp. and Phacus sp. were recorded in Manipur lake. The study was carried out monthly but was tabulated seasonally by using statistical method. From the listed data the quality of water was concluded. Palmer stated that composite rating of algae, tolerating organic pollution and developed an index to establish the status of the aquatic body. In this method to determine the level of organic pollution by studying the algae present in a sample of water.

KEY WORDS...... Manipur lake, Phytoplankton, Density, Pollution index

HOW TO CITE THIS ARTICLE - Mulia, N.R., Kotadiya, N.G. and Acharya, C.A. (2017). Seasonal variation of phytoplankton diversity, density and palmer's pollution index of freshwater lake, rural area of Ahmedabad. Asian J. Animal Sci.,12(1): 70-75. DOI : 10.15740/HAS/TAJAS/12.1/70-75.

ARTICLE CHRONICLE - Received : 19.04.2017; Revised : 15.05.2017; Accepted : 26.05.2017 